\title{
Water Stress, Agricultural water Transfer and Social Equity in the Chaobai Watershed
}

\section{Zhou Yuan and Yang Hong}

\section{(2) OpenEdition \\ 1 Journals}

Electronic version

URL: http://journals.openedition.org/chinaperspectives/3733

DOI: 10.4000/chinaperspectives.3733

ISSN: 1996-4617

Publisher

Centre d'étude français sur la Chine contemporaine

\section{Printed version}

Date of publication: 4 April 2008

Number of pages: $47-56$

ISSN: 2070-3449

\section{Electronic reference}

Zhou Yuan and Yang Hong, "Water Stress, Agricultural water Transfer and Social Equity in the Chaobai Watershed », China Perspectives [Online], 2008/2 | 2008, Online since 01 April 2011, connection on 28 October 2019. URL : http://journals.openedition.org/chinaperspectives/3733 ; DOI : 10.4000/chinaperspectives.3733 


\section{Water Stress, Agricultural}

Water Transfer, and Social

Equity in the Chaobai

Watershed

ZHOU YUAN AND YANG HONG

Water stress has resulted in an increasing trend towards the reallocation of agricultural water to the industrial and municipal sectors. This study examines the impact of water reallocation on crop production and farmers' incomes, and identifies the gap between current levels of financial compensation and the real loss of farmers' incomes based on a survey of 349 farm households and their farm plots in the Chaobai watershed. The results show that the current compensation received by farmers is generally lower than the losses incurred due to reduced irrigation.

A transparent, fair, and legally protected compensation mechanism is required to achieve a long-term water sharing relationship and sustainable water utilisation.

W ater stress is increasingly recognised as a crisis in northern China due to limited water reserves and escalating water demand. In terms of the common threshold of severe water stress of 1,000 cubic meters $\left(\mathrm{m}^{3}\right)$ of renewable water per capita, all three major river basins in northern China - Huaihe, Haihe, and Huanghe (Yellow River) - have water levels below half of this threshold. ${ }^{(1)}$ Additionally, northern China possesses roughly 20 percent of the nation's water resources yet constitutes 64 percent of the land area. ${ }^{(2)}$ The increase in irrigation water usage has been accompanied by increased demand for water by industry, nearly exhausting the supply of water. The consequences of water stress are formidable, including eliminated river flows, falling groundwater tables, and widespread water pollution. Water stress has also intensified water use conflicts between upstream and downstream areas as well as between agriculture and the municipal and industrial sectors. Recent years have seen an increasing trend of reallocation of agricultural water to the industrial and municipal sectors and a compromising of environmental water needs. The Chaobai watershed, which is facing the above mentioned difficulties, is considered as a case study to illustrate the various problems and issues associated with water transfers. The problems being faced in this watershed are characteristic of problems encountered in many other watersheds or rivers in China. Our study area in the Chaobai watershed is located upstream of the Miyun reservoir, which is Beijing's most important source of drinking water. The study area comprises three counties of Hebei Province, namely Chicheng, Fengning, and Luanping, covering an area of $10,877 \mathrm{~km}^{2}$ (see Figure 1). This area is dominated by the continental temperate monsoon climate, where precipitation varies from 350 to $690 \mathrm{~mm}$ and is highly concentrated from June to September. The annual average runoff from this watershed to the Miyun reservoir is about 752 million $\mathrm{m}^{3}$. However, in the past few decades the runoff has declined considerably due to varied precipitation and increased water consumption. Meanwhile, water quality has deteriorated because of soil erosion and wastewater discharge from industry and agriculture. ${ }^{(3)}$

1. X. Cai and M.W. Rosegrant, "Water management and food production in China and India: A comparative assessment," Water Policy, 7(6), 2005, pp. 643-663.

2. China Statistical Yearbook, 2005, http://www.stats.gov.cn/tjsj/ndsj/, accessed January 2008.

3. C. Peisert and E. Sternfeld, "Quenching Beijing's thirst: the need for integrated management for the endangered Miyun reservoir," China Environmental Series, 7 , 2004, pp. 33-45. 
Figure 1. Map of the study area in the Chaobai watershed

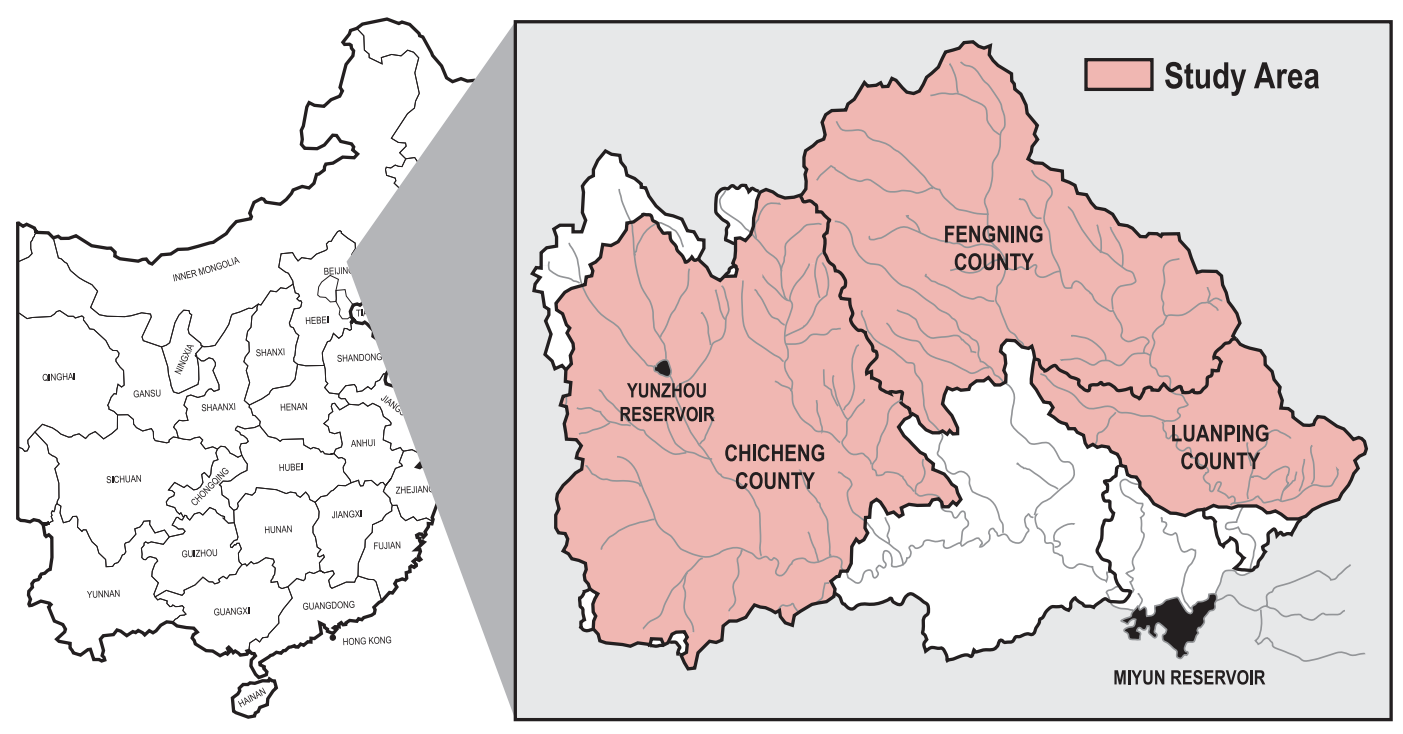

Under this situation, the Beijing authorities have been negotiating with three county governments to reduce their water use, especially in the agricultural sector. The efforts have been twofold: firstly, investments have been made to improve the irrigation infrastructure, combat water and soil erosion, and promote water saving projects. Secondly, a series of interventions and policies have been implemented, such as converting sloping farmland to forest or pasture, designing specific prohibited zones for grazing, water retention during crop growing seasons, and more recently, converting paddy rice to dryland crops. Many of these measures have had adverse impacts on farmers' livelihood and productivity, and only very recently has compensation been considered an issue in the water reallocation arrangement. In implementing the above measures, two important questions have not been carefully investigated. Firstly, to what degree have local farmers become worse off in terms of both production and income loss due to lack of access to irrigation water? Secondly, what is the appropriate level of compensation that farmers should receive for adopting such measures?

Apart from water volume, there has been serious concern over water quality. There are basically two sources of water pollution: one is the so-called point source, such as pollution coming from industry, and the other is non-point source, e.g. from agricultural land, animal husbandry, and soil erosion. As point sources are relatively easy to regulate and control by imposing, for example, restrictions or bans on polluting industries such as metal ore mining in upstream counties, non-point sources have become the primary polluters of the reservoir's water. Wang et al.'s study ${ }^{(4)}$ shows that non-point source pollution contributes to 73 percent of COD (chemical oxygen demand), 94 percent of NH3-N (ammonia nitrogen), 75 percent of total $\mathrm{N}$ (nitrogen) and 94 percent of HPO4 (phosphate ion) in the total pollutant load to the Miyun reservoir. Nutrient loss from fertiliser is one of the main sources of pollution from farmlands.

Drawing on specific household surveys conducted by the authors, this study investigates the impact of reduced irrigation on crop production and household income in this watershed, and attempts to identify the gaps between current compensation levels and farmers' real income loss for the various policy measures. Additionally, this study discusses the issue of water quality, particularly with respect to fertiliser use. Based on the findings, a few policy-relevant implications are discussed, and recommendations for future development are made.

\section{Data and description of farming characteristics}

\section{The household survey}

The data come from a household survey conducted between July and December 2006 in collaboration with the Institute of

4. X. Wang, F. Guo, X. Cai, Q. Hu, "Non-point source pollution loading of Miyun reservoir, Beijing," in Urban Environment \& Urban Ecology, 16(1), 2003, pp. 31-33. 


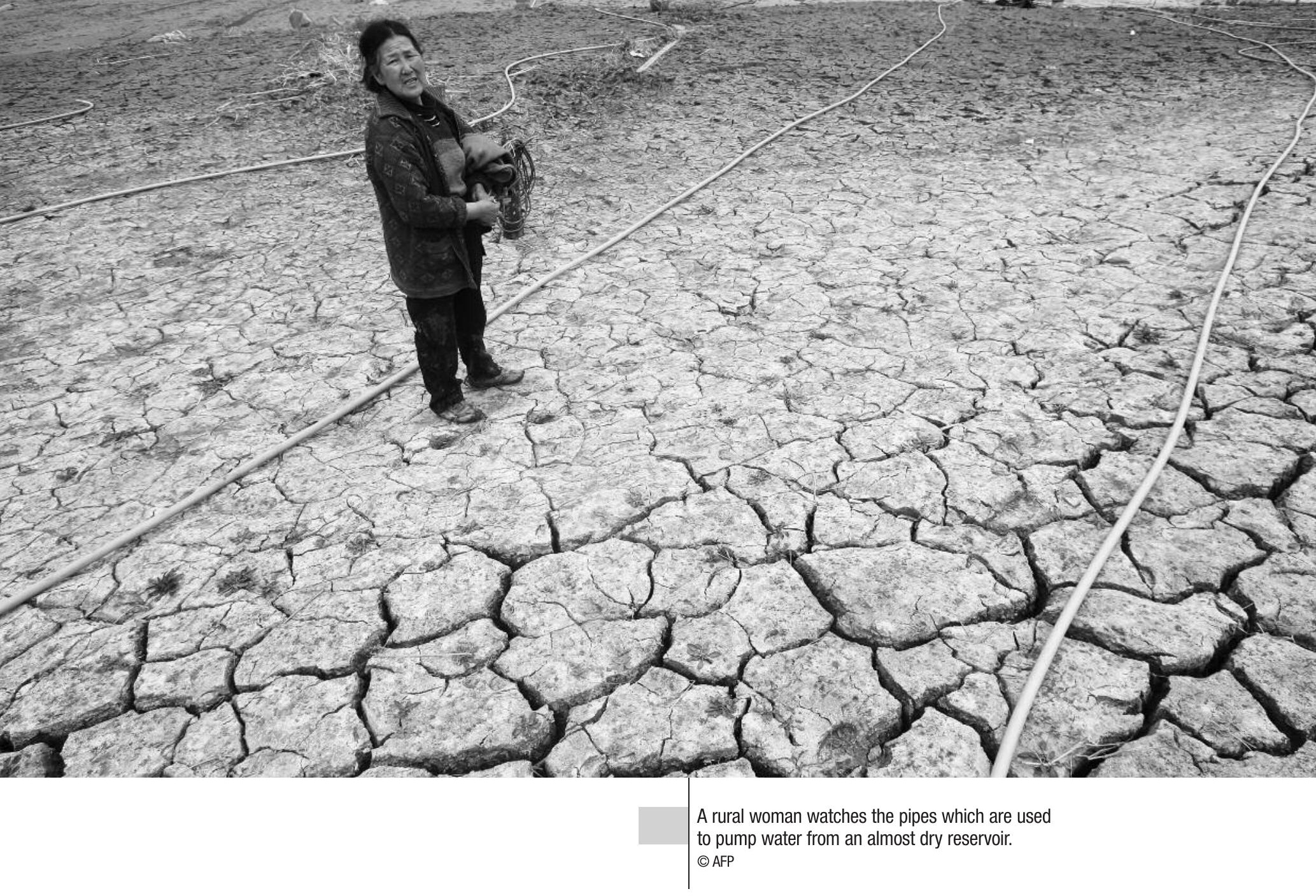

Geographic Sciences and Natural Resources Research at the Chinese Academy of Sciences. In proportion to the area within the watershed and considering the distribution of the rural population, we selected five townships in Chicheng County, four in Fengning County, and two in Luanping County for the survey. The townships are spread over the upstream, mid-stream, and downstream of the watershed. Three representative villages were selected in each township. Around ten households in each village were chosen randomly for faceto-face interviews with the head of each household or with members responsible for farming activities. In total, the survey covered 34 villages and 349 farm households.

The survey questionnaire was designed to elicit information on households' demographic structure, land, and irrigation, farming inputs and outputs, income sources, and decision-making in irrigation and fertiliser application. Interviewers who assisted the researcher in conducting the survey were trained in how to administer the questionnaire. The survey contains, in particular, a series of plot-specific questions such as plot size, irrigation status, ownership, type of soil, soil fertility, distance from home, topography and slope, type of crop, yield, crop intensity, crop rotation, and the occurrence of natural disasters. From each household, detailed information on the three largest plots was collected for the year 2005. In addition, data were collected on total household income and income by source including crop, off-farm, livestock, and other incomes. In this study, crop income refers to gross crop revenues minus production costs, taking into account the market value of crops produced for self-consumption. Off-farm income includes wages for the household's agricultural and non-agricultural work, income from self-run businesses, and migrant remittances. Livestock income comprises the net income generated from animal husbandry, including byproducts. The remaining income is treated as "other income" and may include retirement pensions, earnings from leasing or sales of assets, and other unidentifiable sources.

\section{Farming characteristics}

Agriculture is dominated by small-scale subsistence farming systems, with maize as the main crop. The agro-climatic conditions permit one maize season a year. Other crops include millet, sorghum, beans, and tubers crops. On a small percentage of land, paddy rice and cash crops, such as oil seeds and vegetables are grown. Agricultural water use accounts for more than 70 percent of the water withdrawal in the area. ${ }^{(5)}$ Due to the semi-arid climate and the mountainous

5. W.F.Dong, "Mi yun shui ku shang you 'tui dao huan han' jie shui liang ji qi dui nong min de ying xiang yan jiu" (Study on saved water and effects on farmers with the policy of converting rice to dryland in upper Miyun reservoir), $\mathrm{PhD}$ thesis, Institute of Geographic Sciences and Natural Resources Research, CAS, 2006. 
Table 1. General features of the farmers surveyed and farmland in the Chaobai Watershed

\section{Household characteristics}

\begin{tabular}{l|r|r} 
Household size & 3.3 & 1.2 \\
\hline Number of dependents & 0.76 & 0.8 \\
\cline { 1 - 2 } $\begin{array}{l}\text { Average age of adult members } \\
\text { (years) }\end{array}$ & 48 & 9.8 \\
\begin{tabular}{l|r} 
Average education of adult \\
members (years)
\end{tabular} & 5.5 & 2.6 \\
\hline Total income per capita (yuan) & 2840 & 2109 \\
\hline Farm income per capita (yuan) & 723 & 676 \\
\hline Land area per capita (mua) & 2.96 & 1.96 \\
\hline Irrigated area per capita (mu) & 0.84 & 1.21 \\
\hline Total number of plots & 7.39 & 4.13
\end{tabular}

\section{Plot characteristics}

\begin{tabular}{|c|c|c|}
\hline Maize yield $(\mathrm{kg} / \mathrm{mu})$ & 422 & 128 \\
\hline $\begin{array}{l}\text { Irrigation (1 if irrigated, } 0 \\
\text { otherwise) }\end{array}$ & $36 \%$ & NA \\
\hline Surface water irrigation & $17 \%$ & NA \\
\hline Groundwater irrigation & $19 \%$ & NA \\
\hline Plot size & 1.74 & 1.13 \\
\hline Distance from home (km) & 0.7 & 0.53 \\
\hline Soil fertility ( 1 if fertile, 0 otherwise) & $23 \%$ & NA \\
\hline $\begin{array}{l}\text { Topography ( } 1 \text { if on plain and } 0 \text { on } \\
\text { hill) }\end{array}$ & $85 \%$ & NA \\
\hline $\begin{array}{l}\text { Slope ( } 1 \text { if mostly level, } 0 \\
\text { otherwise) }\end{array}$ & $82 \%$ & NA \\
\hline $\begin{array}{l}\text { Crop rotation ( } 1 \text { if crop is rotated, } 0 \\
\text { otherwise) }\end{array}$ & $4 \%$ & NA \\
\hline Fertilizer use (yuan/mu) & 85.3 & 32.8 \\
\hline $\begin{array}{l}\text { Pesticide application ( } 1 \text { if pesticide } \\
\text { is applied, } 0 \text { otherwise) }\end{array}$ & $31 \%$ & $N A$ \\
\hline $\begin{array}{l}\text { Manure application ( } 1 \text { if manure is } \\
\text { applied, } 0 \text { otherwise) }\end{array}$ & $26 \%$ & NA \\
\hline
\end{tabular}

a1 $m u=1 / 15$ hectare $N A$ : not applicable

Source: Authors' survey environment, most crops are rain-fed, and irrigated land accounts for less than 20 percent of the total arable land. ${ }^{(6)}$ Surface irrigation is characterised by obsolete canals, substantial leakage, and an unreliable water supply, and is free of charge. In contrast, groundwater users have to pay for the cost of pumping, which on average amounts to about 20-25 RMB per mu (Chinese land unit, $1 \mathrm{mu}=1 / 15$ hectare), about 14 percent of total capital expenses in the case of maize farming. Fallow or routine rotation of crops is rarely practiced in the region. Nutrient replenishment is based almost exclusively on the application of manure and chemical fertiliser.

The study area has a low income, and all three counties are categorised as poor counties at a national level. A considerable number of the younger generation have left home and sought employment elsewhere, as they do not consider farming attractive. Local farmers struggle to improve their standard of living by generating off-farm income through seasonal work. This includes small trade activities or working elsewhere as drivers or construction labourers, or in boilers during off-farm periods. As employment opportunities and earnings are limited, the area remains under-developed. Poverty reduction is one of the pressing issues that need to be dealt with. The general characteristics of the farmers surveyed are shown in Table 1.

\section{Impact of agricultural water transfer on crop yield and household income}

Water transfer from upstream agriculture to downstream municipal and industrial uses has caused direct reduction in irrigation water in the study area. Its impact can thus be analysed by examining the effects of reduced irrigation on crop yield and household income. As the affected areas are located in part of the study area, this has been done by examining the differences in crop yields and income between farm households with and without irrigated land. The extensive literature review on the subject suggests that there are strong linkages between irrigation and poverty. ${ }^{(7)}$ Direct linkages operate via localised and household level effects, and indirect linkages operate via aggregate or sub-national and national level impacts. Irrigation benefits smallholder farmers through higher production, higher yields, lower risk of

6. Ibid.

7. I. Hussain, M. A. Hanjra, "Irrigation and poverty alleviation: review of the empirical evidence," Irrigation and Drainage, 53, 2004, pp. 1-15. 
Table 2. Impact of irrigation on maize yield

\begin{tabular}{|c|c|c|}
\hline & \multicolumn{2}{|c|}{ Dependent variable: Log (Maize yield) } \\
\hline & Model 1 & Model 2 \\
\hline Constant & $5.45^{\star * *}(57.29)$ & $5.46^{\star * *}(57.16)$ \\
\hline \multicolumn{3}{|l|}{ Irrigation status } \\
\hline Irrigated & $0.21^{* * *}(11.1)$ & \\
\hline Surface water irrigated & & $0.17^{\star * *}(7.43)$ \\
\hline Groundwater irrigated & & $0.24^{* * *}(10.42)$ \\
\hline \multicolumn{3}{|l|}{ Household features } \\
\hline Household size & $-0.003(-0.36)$ & $-0.003(-0.42)$ \\
\hline Average age of adults (years) & $0.001(1.22)$ & $0.001(1.21)$ \\
\hline Average education of adults (years) & $0.02^{* * *}(3.8)$ & $0.01^{* * *}(3.52)$ \\
\hline Land area per plot (mu) & $0.02^{* *}(2.48)$ & $0.02^{* *}(2.43)$ \\
\hline \multicolumn{3}{|l|}{ Plot characteristics (omitted)a } \\
\hline Number of plots & $870^{b}$ & 870 \\
\hline Number of households & $339 c$ & 339 \\
\hline $\mathbf{R}^{2}$ & 0.41 & 0.41 \\
\hline \multicolumn{3}{|c|}{$\begin{array}{l}\text { The } t \text { statistics are in parentheses. }{ }^{* *} \text { Siginificance at } 1 \%,{ }^{*} \text { Significance at } 5 \%,{ }^{*} \text { *ignificance at } 10 \% \text {. } \\
\text { a: Plot characteristics are not reported to save space. Full table is available upon request. } \\
\text { b: Observations with missing data for independent variables are deleted from the sample. } \\
\text { c: Ten households are excluded from the sample as they grow maize seeds instead of normal maize. }\end{array}$} \\
\hline
\end{tabular}

crop failure, and higher and year-round farm and non-farm employment.

In this area, maize has the highest yield and is most suitable to grow under local climate conditions, according to farmers surveyed. Although it is not the main staple food, maize plays an essential role in satisfying food needs through exchange or trade, and in generating income and providing fodder for livestock. In our survey, the main food sources were solicited. In all the samples, 70 percent of the households identified "selling maize to purchase grain" as one of the main sources of food, while 36 percent identified "trade of maize for wheat or rice." In contrast, only 5 percent of the households depend entirely on purchased food. The subsequent analysis will focus on maize to illustrate the impact of irrigation on crop yield.

Irrigation contributes to agricultural production mainly in two ways. One is through the increase in crop yield and the other is through increasing cropping intensity and/or switching to high-value crops. The latter is not considered here due to inadequate data for the period before intervention, especially regarding crop-switching. Hence our estimates will be on the conservative side. By comparing maize yields under different irrigation conditions using plot level data directly derived from our survey, we find that on average the yield under irrigation is $118 \mathrm{~kg} / \mathrm{mu}$ (31 percent) higher than for non-irrigated land. Within irrigated land, maize with groundwater irrigation has a 14 percent higher yield than with surface irrigation, and the difference is statistically significant. This finding is consistent with Dhawan, ${ }^{(8)}$ showing that groundwater irrigation performs better than surface water because farmers have better control over supply.

To investigate the true relationship between irrigation and yield, other factors that contribute to higher yields on irrigated land (e.g. soil fertility) need to be accounted for. An empirical model is developed taking into account the household features, as well as detailed plot-specific characteristics. Household features include the experience and education of the household's members, the number of labourers, fertiliser application, capital and land endowment, and choice of seeds, among others. Plot-intrinsic factors include access to irrigation, soil quality, plot size, topography, slope, and distance from home. The model is estimated by Ordinary Least Squares using robust standard errors. ${ }^{(9)}$ The positive

8. B. D. Dhawan, "Irrigation in India's agricultural development: Productivity, stability, equity," Delhi, Institute of Economic Growth, Sage publications, 1988.

9. H. White, "A heteroskedasticity-consistent covariance matrix estimator and a direct test for heteroskedasticity," Econometrica, 48, 1980, pp. 817-838. 
Table 3. Sources of household income according to irrigated farm size

\begin{tabular}{l|r|r|r|r}
\hline \hline Per capita irrigated land (mu) & All & \multicolumn{1}{|c|}{$<$} & $1-2$ & $>\mathbf{2}$ \\
\hline Number of households & 347 & 233 & 70 & 44 \\
\hline Total land area per capita (mu) & 2.95 & 2.8 & 2.56 & 3.21 \\
\hline Total income per capita (yuan) & 2840 & 2596 & 3283 & 3423 \\
Crop income & 723 & 589 & 845 & 1240 \\
Livestock income & 309 & 294 & 270 & 450 \\
Off-farm income & 1592 & 1499 & 1876 & 1630 \\
Other income & 215 & 214 & 290 & 103 \\
\hline Shares in total income & & & & \\
Crop income & 0.25 & 0.23 & 0.26 & 0.36 \\
Livestock income & 0.11 & 0.11 & 0.08 & 0.13 \\
Off-farm income & 0.56 & 0.58 & 0.57 & 0.48 \\
Other income & 0.08 & 0.08 & 0.09 & 0.03 \\
\hline
\end{tabular}

coefficient for irrigation (see Table 2) means that on irrigated land maize yield is 21 percent higher, equivalent to 85 $\mathrm{kg} / \mathrm{mu}$. This amount is lower than the 31 percent directly derived from descriptive statistics, indicating that the higher yield on irrigated land is partly attributable to other explanatory plot or household-related factors. By dividing irrigation into surface and ground water, the results suggest that plots with surface water irrigation have a 17 percent higher yield than those that are non-irrigated, while with groundwater it is 24 percent higher. Our survey suggests that the quantity, frequency, and timing of groundwater irrigation are more reliable, which helps to ensure a higher yield. The results show that maize yield is reduced considerably if the farmland is deprived of access to irrigation water.

In addition to crop yield, the impact of reduced irrigation on household income is investigated. The survey based the definition of income on cash payments and two additional components: agricultural output produced for self-consumption valued at market price, and payments in kind valued at market price. On average, a household in the study area has an annual net income of about 2,840 RMB per capita, of which $723 \mathrm{RMB}$ is from crop income. Among all sources of household income, 25 percent is generated from farming and 11 percent from livestock husbandry, while 56 percent of the income stems from non-farm employment and 8 percent from other sources. Although crop income accounts for only 25 percent, farmers are dependent on their land for food consumption and regard farming as an essential source of livelihood and security. To study the importance of irrigation for household income, we analysed the sources of income for households classified according to irrigated land area per capita measured in mu (see Table 3).

Table 3 shows a positive correlation between irrigation and per capita income. As per capita irrigated area in a household increases, the absolute value of both total income and crop income also increases. For example, compared to households with per capita irrigated areas of less than $1 \mathrm{mu}$, crop income is 43 percent higher for those with 1-2 mu and 113 percent higher with more than $2 \mathrm{mu}$. Other sources of income, however, do not exhibit such a continuously increasing trend. Another finding is that cropping becomes a more important source of income as per capita irrigated area expands. For example, crop income accounts for only 23 percent of income for households with per capita irrigated land of less than $1 \mathrm{mu}$, but it increases to 36 percent for those with over $2 \mathrm{mu}$. In particular, there is a substantial increase in the share when irrigated land is above $2 \mathrm{mu}$, indicating an enormous economic gain in both farm and total income. This implies that new irrigation projects will facilitate the process of poverty alleviation, in particular for the poor, if designed to expand the irrigated area above the limit of $2 \mathrm{mu}$ per capita. 
To gain a better understanding of how irrigation affects the varying sources of income, a more robust analysis such as multivariate analysis is needed to address the correlations. We follow standard approaches on income analysis, in which income is defined as a function of many determinants, including both household and locational characteristics. ${ }^{(10)}$ The factors influencing household income were grouped into four categories: land assets, human capital, other household assets, and village features. For land assets, the size of irrigated land per capita, the focus of our study, is used to capture the irrigated land holdings. Rain-fed cultivated area per capita accounts for the remaining land holdings, and the number of total plots is used to capture the degree of land fragmentation. Human capital includes the average age and education of adult members, as well as the number of dependent members. The average level of education in the household proves to be a better explanatory variable of household income than education of the household head. ${ }^{\text {(II) }}$ The "other household assets" is reflected by the value of agricultural machinery a household owns and the value of draught animals. Village features are captured by a set of variables: distance from townships, percentage of hilly area in the village, fixed phone connections, the ownership of dug or tube-wells, and the number of village factories.

Ordinary Least Squares are used to estimate income functions for total and crop income, while Tobits are used in livestock and off-farm income estimations. Similar models on household income have been widely used in the literature. ${ }^{(12)}$ The regression results show that losing irrigation on 1 mu of land decreases crop income by 343 RMB and total income by 478 RMB. Compared with rain-fed agriculture, we find that converting irrigated land to rain-fed land would result in a decrease in crop income of $162 \mathrm{RMB}$ and in total income of 227 RMB. It is evident that irrigation has a spillover effect on farm income, as reduction in irrigation leads to a greater loss in total income. Irrigation is, however, not a significant factor in livestock and off-farm income.

\section{Compensation and social equity in agricultural water transfer}

The importance of irrigation in increasing rural household income and the larger demand for water in Beijing presents a conflict over limited water resources in the Chaobai watershed. In this situation, methods for making appropriate water compensation arrangements and thereby achieving "social equity" becomes crucial. Social equity implies fair ac- cess to water resources and livelihood; the concept of what is "fair" reflects the ethical values shared by society, as well as economic values associated with resource use. ${ }^{(13)}$

Since the 1990s, the Miyun reservoir has become the most important supplier of Beijing's drinking water as a consequence of water quality degradation in another reservoir, Guanting. Great attention has since been paid to ecological protection of upstream areas of the Miyun reservoir for Beijing's water security. A set of policy interventions has been introduced aiming at water and soil conservation, water saving, water pollution control, and the development of waterfriendly ecological agro-economic zones. ${ }^{(14)}$ Among these, three policy interventions have had the most profound impact on farmers in the Chaobai watershed. These are retaining water in the Yunzhou reservoir in the Bai River, converting paddy rice to dryland crops, and converting sloping land to forest or pasture.

Based on our survey, the Yunzhou reservoir has been retaining water during crop growing seasons and otherwise redirecting it to Beijing since 2003. It provided water to Beijing in 2004 and 2005 by releasing 10 million $\mathrm{m}^{3}$ and 18 million $\mathrm{m}^{3}$, respectively, to the downstream Miyun reservoir. ${ }^{(15)}$ This water diversion has caused a drastic reduction in irrigated land and forced a change of crops. Before 2003, farmers grew paddy rice and vegetables that required irrigation. After the water diversion, only maize and dryland crops could be planted, with the most severe effect felt in the three townships of Yunzhou, Chicheng, and Yangtian, located directly downstream of the reservoir. In one of the villages surveyed in Yunzhou Township, the village leader revealed that the entire irrigated area of $400 \mathrm{mu}$ was lost due to this intervention. According to our early estimates, this would imply an economic loss of 90,800 RMB per year in total household income, of which 64,800 RMB is from crop income. In other words, an average household in the village would have lost income of 1,009 RMB per year. This intervention

10. A. De Janvry and E. Sadoulet, "Income strategies among rural households in Mexico: The role of off-farm activities," World Development, 29 (3), 2001, pp. 467-480.

11. D. Jolliffe, "Whose education matters in the determination of household income: Evidence from developing country?" International Food Research Centre, Food consumption and nutrition division, FCND discussion paper No. 39, 1997.

12. A. De Janvry and E.Sadoulet, op. cit.; L. Corral and T. Reardon, "Rural non-farm income in Nicaragua," World Development, 29 (3), 2001, pp. 427-442.

13. X. Cai, "Water stress, water transfer and social equity in Northern China-Implications for policy reforms," Journal of Environmental Management, In Press, doi: 10.1016/j.jenvman.2006.12.046, 2008.

14. See Web site http://www.hwcc.com.cn/newsdisplay/newsdisplay.asp?ld=77595, accessed May 2007.

15. See Web site http://news.xinhuanet.com/society/2005-11/02/content_3719122.htm, accessed June 2007 

delayed. In one of the villages, farmers received only 60 percent of the compensation due to them. In a neighbouring village, compensation payments have not yet been received, and farmers complained about less staple food for consumption.

The third intervention is "converting sloping farmland to forests and pastoral land," the so-called "grain for green" policy. This program was launched in 2002 in our study area and targeted at lands with 15 degrees or more of slope. Although it does not relate directly to water diversion from agriculture, it affects agriculture for water protection reasons. This program offers compensations to farmers in the form of grain, cash, and seedlings. In our survey, 61 percent of farm households have adopted the policy. The current compensation is 140 or $160 \mathrm{RMB}$ in cash per year, lasting for five to seven years depending on the type of trees planted. While the policy's criteria and compensation levels are clear, we found that the selection of the plots for the program was influenced by village authorities and limited by quotas. In some cases, only part of the actual area of the plot was taken into account in determining compensation, although the whole plot has been converted to forest. In other cases, different levels of compensation were given for similar plots, and were implemented, moreover, without transparency. Another factor stems from the gap between the current level of compensation and the net income otherwise obtained by growing crops. Based on our calculations, the loss of $1 \mathrm{mu}$ of rainfed land would reduce net crop income by 181 RMB and total household income by 251 RMB. This, however, could not be taken directly as a benchmark due to reduced losses expected on sloping land. Nevertheless, our survey reveals that for some farmers a higher compensation, ranging from 200 to $300 \mathrm{RMB} / \mathrm{mu}$, would be more acceptable. Hence, the need for different levels of payments should take into account the land quality and previous crop income.

In summary, the policy measures to decrease water use in our study area to ease water stress in Beijing have brought stress to local farmers. Although farmers may have an interest in overstating their willingness to accept the measures mentioned above, our analyses are based mainly on the differences in yields among households rather than farmers' estimates of loss. As the weakest group, they deserve to be adequately remunerated for their losses in livelihoods and income. If this issue is not addressed with sufficient fairness, the aim of sustainable delivery of water to Beijing and its environs may not be realised in the near future.

\section{Water quality and fertiliser use in farmland}

Besides water reallocation, the quality of water has also been a concern. The level of fertiliser and pesticide use, as well as farming practices in the region, has a great impact on water quality downstream. Nutrient loss from agricultural land has been partially responsible for the eutrophication and degradation of water quality in the Miyun reservoir. As elsewhere in China, farmers in this area tend to apply significant amounts of fertiliser. For example, our survey showed that a typical maize farmer applies $12 \mathrm{~kg} / \mathrm{mu}$ of phosphate fertiliser in conjunction with $27 \mathrm{~kg} / \mathrm{mu}$ of urea (nitrogen fertiliser). Compared with maize, less fertiliser is used on coarse grains and more is applied to paddy rice. In general, farmers tend to favour the use of nitrogen fertiliser, but undervalue the effects of phosphorous and potassium fertilisers. The ratio of $\mathrm{N}$ and $\mathrm{P}_{2} \mathrm{O}_{5}$ (phosphorus pentoxide) application is approximately 1: 0.38 in the area surveyed. This ratio diverges significantly from the recommended ratio of 1 : 0.6-0.7 for the region. ${ }^{(17)}$ Overuse of nitrogen fertiliser is prevalent, and can result in not only low efficiency and large losses, but also a negative impact on the atmospheric environment and water quality.

In order to inform policy makers about reducing pollution from farmland, it is essential to understand how farmers make fertiliser use decisions. This has high relevance for formulating effective intervention strategies. This study considers both farmers' subjective evaluations of the factors shaping their decisions on fertiliser use, and the influence of farm and farmer-specific characteristics. Our survey contains a series of questions relating to farmers' subjective assessments of the factors influencing their decisions. Farmers were asked to list the most influential factors coming into their minds when deciding how much fertiliser to use. Additionally, farmers were asked to rate the decision variables according to the importance and degree of uncertainty. The results show that farmers' own experiences with fertiliser and yield gain from fertilisation are very important for their decisions on how much fertiliser to use, while the cost of fertiliser, capital availability, expected work in its application, and social influences (including neighbours and institutional influence) are not important. The low importance of social influence suggests that farmers in the study area receive very few agricultural extension services on fertiliser application and essentially make decisions on their own. The absence of

17. See Web site http://www.heagri.gov.cn/hbagri/html/234/39316.htm 
guidance in determining appropriate levels of fertilisers for their land may lead to high levels of nitrogen fertiliser application.

In addition, an empirical analysis was conducted with fertiliser use per land area as the dependent variable and a set of farm and farmers specific factors as independent variables to explain the variation in fertiliser use intensity across farms. The results show that irrigation and expected gains in crop yield are positively correlated to fertiliser use, while farm size, manure application, soil fertility, and the distance to fertiliser markets are negatively correlated. The financial constraints of the household play a trivial role in influencing fertiliser use, implying that the farmers make decisions independent of capital availability in this area. Investigation of the overuse problem shows that education significantly reduces the probability of overuse of nitrogen.

\section{Strategies and conclusions}

Our study, based on household survey data, clearly shows that water reallocation from agriculture to Beijing in the Chaobai watershed has decreased farmers' crop production and compromised their welfare at current levels of infrastructure and technology. We discussed the effects of three major interventions on local farmers in the study area and found that in all cases a better mechanism of compensation is needed to achieve social equity in water sharing and reallocation. It is therefore necessary to establish compensation mechanisms in our study area and in other water protection zones that are transparent, fair, and protected by law. It is also important to ensure that upstream stakeholders who carry out water conservation work are appropriately funded and are involved in the land and water use decision-making processes.

Improving water use efficiency by investing in water-saving technologies and irrigation infrastructure is indispensable under water stress conditions. Other aspects of policy implications for successful water transfers include the establishment of effective water management, the use of feasible water prices, delineation of secure and consistent water rights, and the reconsideration of national agricultural policies. In addition, water management reform of irrigation systems is badly needed in our study area, including institutional reforms as well as incentives to water managers and farmers to save water. Equally important is to adopt integrated river basin management through which coordinated conservation, management, and development of water resources across sectors and regions can be achieved. Only by addressing these issues can a smooth and fair long-term relationship over water be ensured between our study area and Beijing.

With respect to water quality, it is important to achieve an appropriate balance of nitrogen, phosphate, and potassium fertilisers in farmland, and to restrain the overuse of nitrogen. Many farmers expressed concern over their lack of knowledge of the soil nutrient content of their land, and stressed the importance of field soil experiments. These concerns imply that in this region education and extension services should concentrate on educating farmers about understanding their soil and recognising the importance of balanced fertiliser application, fine-tuning their fertiliser use practices to improve the efficiency of fertiliser use, and reducing the overuse of nitrogen.

Sustained efforts are needed to strengthen general rural education and to enhance the dissemination of technical advice to farmers. Improving rural extension services and on-site demonstrations will be beneficial to farmers by providing knowledge of soil quality and raising awareness of the negative effects of excess fertiliser use. As weather conditions are important in deciding on fertiliser application, the provision of timely local weather forecasts would also help farmers evaluate the risks and determine the appropriate amounts to apply. The significance of manure application suggests that organic fertilisers should be promoted in this area, as it can offset the use of chemical fertilisers. Green manure should also be promoted in this region for its nutrients and organic matter contributions to the soil. Furthermore, ecological agriculture should be developed in this area by making use of eco-friendly technologies, combined with traditional physical and cultivation measures, taking into consideration the quality of the soil, the availability of water, and the potential for investment. 